CARTA AL EDITOR

\section{PATÓGENOS EN LÍQUIDO CEFALORRAQUIIDEO IDENTIFICADOS EN UN LABORATORIO PARTICULAR DE REFERENCIA EN LIMA, PERÚ}

\section{PATHOGENS IDENTIFIED IN CEREBROSPINAL FLUID FROM A PRIVATE REFERENCE LABORATO- RY IN LIMA, PERU}

\author{
Juan Carlos Gómez-de-la-Torre (1),a,b, Juan José Montene- \\ gro-Idrogo (iD)2,3,a , Alfredo Juan Chiappe-Gonzalez (1D2,4,a \\ 1 Laboratorios ROE, Lima, Perú. \\ 2 Servicio Enfermedades Infecciosas y Tropicales. Hospital Nacional Dos de \\ Mayo, Lima, Perú. \\ ${ }^{3}$ Facultad de Ciencias de la Salud, Universidad Científica del Sur, Lima, Perú. \\ ${ }^{4}$ Clínica Angloamericana, Lima, Perú. \\ a Médico infectólogo; ${ }^{\text {b }}$ Médico patólogo clínico
}

Sr. Editor: El objetivo de la presente comunicación es describir la distribución geográfica de los resultados de 500 muestras de líquido cefalorraquídeo (LCR) de niños y adultos, obtenidos mediante la técnica molecular FilmArray en la Unidad de Genética y Biología Molecular de Laboratorios Roe del distrito de Magdalena del Mar, en Lima Metropolitana, Perú, durante 2017 al 2019. Obtuvimos 100 (20\%) muestras positivas a algún microorganismo, de las cuales $89 \%$ fueron de procedentes de Lima. La distribución geográfica de los pacientes con infecciones del sistema nervioso central se presenta en la Figura 1.

La mediana de edad de los pacientes para infecciones bacterianas fue de 32 años con un rango intercuartílico (RIQ) de 9 a 52, en infecciones virales de 32 años (RIQ: 12-44) y fúngicas de 25 años (RIQ: 13-60). Las principales etiologías encontradas fueron enterovirus (24\%), Cryptococcus neoformans (16\%), Streptococcus pneumoniae (15\%), Listeria monocytogenes (12\%), virus herpes humano 6 (VHH6) (12\%), virus herpes simple 1 (VHS-1) (7\%), virus herpes simple 2 (VHS-2) (5\%), Haemophilus influenzae tipo b (HIB) (3\%), virus varicela zoster (VVZ) (3\%), Escherichia coli (2\%) y Neisseria meningitidis (1\%).

La etiología viral de encefalitis esporádica más frecuente es el VHS-1, estipulando que la sospecha clínica debe inducir el inicio de terapia antiviral empírica. Sin embargo, en nuestro estudio el enterovirus fue la etiología más frecuente, siendo los distritos con más casos, el cercado de Lima, seguida de Ate, San Isidro y San Martín de Porres. Estos resultados son concordantes con los reportados por Espinoza y col, quienes

Citar como: Gómez-de-la-Torre JC, Montenegro-Idrogo JJ, Chiappe-Gonzalez AJ Patógenos en líquido cefalorraquídeo identificados en un laboratorio particular de referencia en Lima, Perú. Rev Peru Med Exp Salud Publica. 2021;38(1):185-6. doi: https://doi.org/10.17843/rpmesp.2021.381.5487.

Recibido: 04/04/2020 Aprobado: 14/10/2020 En línea: 27/01/2021 describen los hallazgos de 97 niños con infección del sistema nervioso central (SNC) por enterovirus entre 2008 al 2010.

Se identificó al enterovirus en el 53\% del total de infecciones agudas no bacterianas del SNC (30\% procedían del distrito de San Martín de Porres) además de representar el 83\% y 39\% de las meningitis agudas asépticas y encefalitis agudas respectivamente ${ }^{(1)}$. Se ha descrito, que los enterovirus presentan una conducta estacional al igual que los virus respiratorios ${ }^{(2)}$; no obstante, en nuestro estudio, los casos de infección del SNC por enterovirus no tuvieron un patrón estacional específico.

No existen estudios nacionales que describan la frecuencia de encefalitis por otros virus herpes como el VHH-6. Sabemos que su principal asociación es con roséola y cuya complicación a manera de encefalitis se describe preferentemente en inmunocomprometidos ${ }^{(3)}$ En nuestro estudio, la positividad al VHH-6 fue del $12 \%$, más frecuente en pacientes del Callao, y representa el $24 \%$ del total de etiologías virales (enterovirus es el patógeno más frecuente con 47\%); seguido del 13\%, 9\% y 7\% descrito para VHS-1, VHS-2 y VVZ respectivamente.

Estos resultados no representan categóricamente infección activa del SNC, puesto que la positividad del VHH-6 en muestras de LCR no indican necesariamente enfermedad. Se ha descrito la capacidad de este virus de permanecer en estado latente en el tejido cerebral y glándulas salivales, sin que ello genere mayor efecto patogénico en el huésped ${ }^{(4)}$. La ausencia de datos clínicos en este estudio limita la interpretación precisa de este hallazgo.

Por otro lado, Streptococcus pneumoniae es el patógeno más frecuente de meningitis bacteriana en niños mayores de dos meses y adultos. Dávalos y col. describen en Perú 44 casos de meningitis neumocócica en menores de 16 años (68\% menores de 2 años) desde el 2006 al 2011, con una tasa de mortalidad de $33 \%{ }^{(5)}$. Nuestros datos describen $15 \%$ de las muestras procesadas atribuidas a Streptococcus pneumoniae, representando de igual manera la etiología bacteriana más frecuente (43\%). La mayoría de estos casos provino de los distritos de San Juan de Lurigancho (20\%) y La Victoria (20\%), seguido por el cercado de Lima (13,3\%).

Finalmente, se reporta Listeria monocytogenes en el $12 \%$ de las muestras, significando el 37\% de etiologías bacterianas, cifras distintas de la descrita por Lewis y col, quienes reportaron en 53 neonatos con meningitis, a Listeria monocytogenes como causa bacteriana más frecuente en el $20 \%$ y $16 \%$ de las formas tempranas y tardías respectivamente, pero no se reportó los distritos de procedencia ${ }^{(6)}$. En nuestro estudio un alto porcentaje de dichos casos fueron de los distritos San Martín de Porres (25\%), seguido por Los Olivos $(8,3 \%)$, el cercado de Lima (8,3\%), Ate $(8,3 \%)$, Surco $(8,3 \%)$, Callao $(8,3 \%)$ y La Victoria $(8,3 \%)$. 

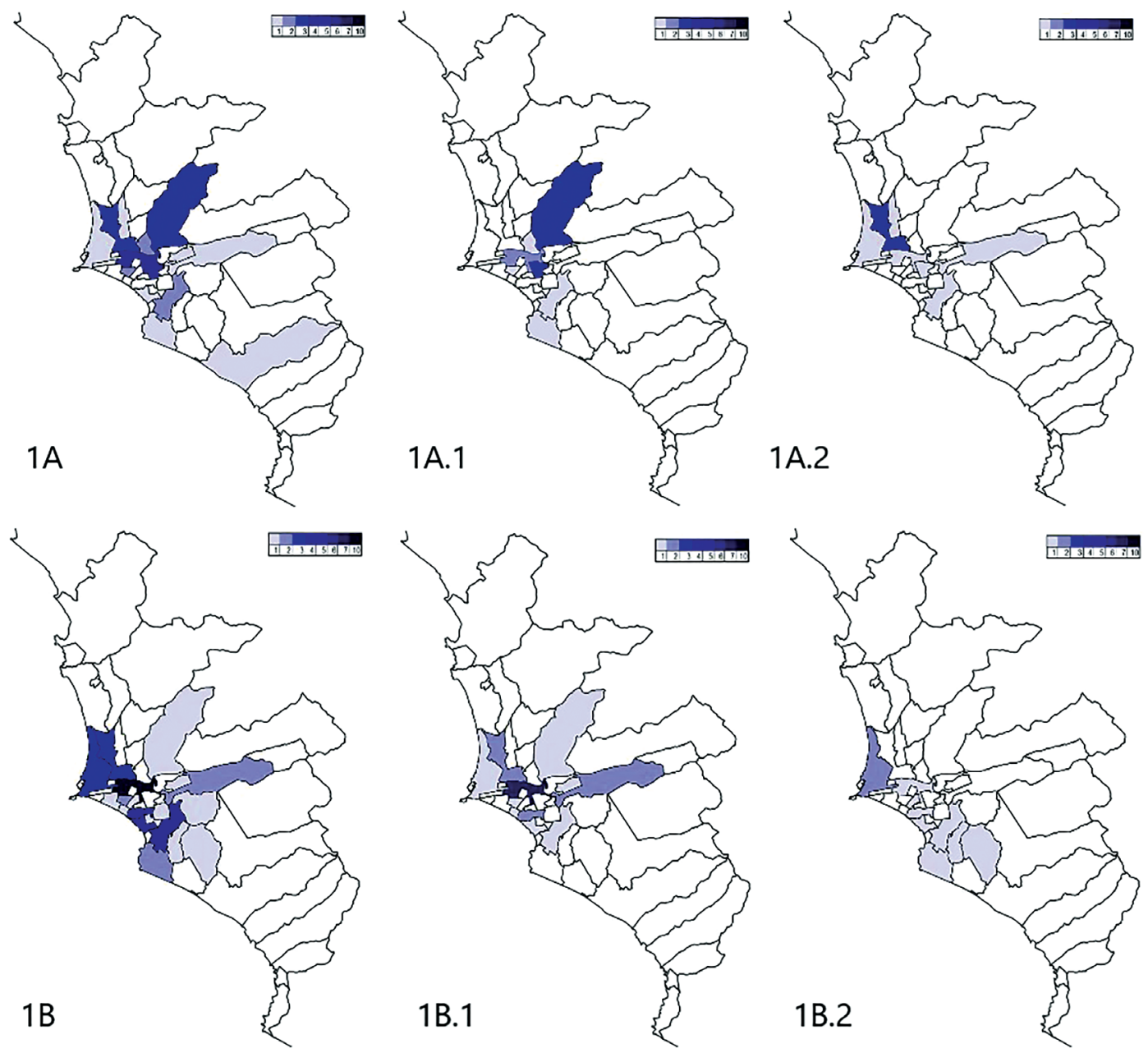

(1A) etiología bacteriana; (1A.1) Streptococcus spp; (1A.2) Listeria spp; (1B) etiología viral; (1B.1) enterovirus; (1B.2) virus herpes humano 6.

Figura 1. Distribución en Lima y el Callao de pacientes con infecciones del sistema nervioso central diagnosticadas mediante FilmArray de líquido cefalorraquideo.

A pesar de las limitaciones, como la ausencia de información clínica para determinar el diagnóstico preciso de los pacientes, es necesario considerar que la toma de LCR y la solicitud del análisis de la misma por parte de los clínicos suelen ejecutarse ante una elevada sospecha de infección del SNC y no como un análisis de rutina. Por lo tanto, consideramos relevante la información descrita con respecto a la distribución de los principales patógenos en Lima a través del empleo de un método diagnóstico molecular rápido.

Contribuciones de autoría: AJCG, JJMI y JCG han participado en la concepción del artículo y su redacción. JCG y JJMI realizaron la recolección y análisis estadístico de los datos. AJCG, JJMI y JCG hicieron la interpretación de los datos y revisión crítica del artículo. AJCG y JCG realizaron las correcciones. JCG realizó la aprobación de la versión final.

Financiamiento: Autofinanciado.

Conflictos de interés: Los autores declaran no tener conflictos de interés.

\section{REFERENCIAS BIBLIOGRÁFICAS}

1. Espinoza IO, Ochoa TJ, Mosquito S, Barletta F, Hernández R, Medina $\mathrm{MP}$, et al. Infecciones del sistema nervioso central por enterovirus en niños atendidos en un hospital de Lima, Perú. Rev Perú Med Exp Salud Pública. 2011;28(4): 602-609.

2. Whitley RJ, Kimberlin DW. Viral encephalitis. Pediatr Rev. 1999;20(6):192-8.

3. Baquedano I, Bernadó R, Laliena S, Bustillo M, Guerrero C. Encefalopatía por virus herpes 6 como complicación de exantema súbito. Arch Argent Pediatr. 2018; 116(2):e312-e314. doi: 10.5546/aap.2018.e312.

4. King O, Al Khalili Y. Herpes Virus Type 6. In: StatPearls [Internet]. Treasure Island (FL): StatPearls Publishing; 2020-. Disponible en: https:// www.ncbi.nlm.nih.gov/books/NBK540998/.

5. Davalos L, Terrazas Y, Quintana A, Egoavil M, Sedano K, Castillo ME, et al. Características epidemiológicas, clínicas y bacteriológicas de meningitis neumocócica en pacientes pediátricos de Lima, Perú. Rev Perú Med Exp Salud Pública. 2016; 33(3): 425-431. doi: 10.17843/rpmesp.2016.333.2349.

6. Lewis G, Schweig M, Guillén-Pinto D, Rospigliosi ML. Neonatal meningitis in a general hospital in Lima, Peru, 2008 to 2015. Rev Peru Med Exp Salud Pública. 2017;34(2):233-238. doi: 10.17843/rpmesp.2017.342.2297. 